\title{
PARAMETER BIOMETRIK HASIL TANGKAPAN PUKAT CINCIN DI LAUT JAWA TERKAIT DENGAN KERAGAAN SELEKTIVITAS
}

\author{
Wijopriono') dan Mahiswara') \\ 1) Peneliti pada Balai Riset Perikanan Laut, Muara Baru-Jakarta \\ Teregristrasi I tanggal: 25 Maret 2008; Diterima setelah perbaikan tanggal: 23 April 2008; Disetujui terbit tanggal: 14 Mei 2008
}

\begin{abstract}
ABSTRAK
Pukat cincin merupakan alat tangkap utama perikanan pelagis di Laut Jawa dengan sasaran kelompok ikan pelagis kecil. Nelayan menggunakan mata jaring ukuran $19 \mathrm{~mm}$ (bagian kantong) dan $25 \mathrm{~mm}$ (bagian badan dan sayap). Sementara itu, pemerintah telah menetapkan ukuran mata jaring minimal $25 \mathrm{~mm}$ (bagian kantong) dan $51 \mathrm{~mm}$ (bagian sayap). Penelitian terhadap pukat cincin telah dilakukan untuk mengevaluasi selektivitas alat tangkap tersebut dan resistensi nelayan dalam menerapkan regulasi yang telah ditetapkan. Evaluasi selektivitas dilakukan melalui pendekatan karakteristik biometrik. Wawancara dilakukan untuk mengetahui masalah resistensi nelayan terhadap regulasi. Berdasarkan pada perbandingan antara hubungan fungsional parameter biometrik ikan sasaran tangkap dan bukaan mata jaring, rentang ukuran panjang ikan yang terjerat telah diestimasi. Diketahui bahwa pada ukuran mata jaring yang sama, ikan dapat terjerat pada ukuran panjang cagak (FL) yang berbeda tergantung dari morfologi. Hasil estimasi maupun aktual ikan yang terjerat menunjukkan kecenderungan yang sama, di mana rata-rata ukuran $D$. russelli dan $S$. crumenophthalmus yang terjerat lebih kecil dari $D$. macrosoma maupun $R$. kanagurta. Fakta bahwa aktual rentang ukuran ikan yang terjerat $25 \%$ lebih kecil dan $13 \%$ lebih besar dari hasil estimasi. Hal ini, membuktikan ada pengaruh faktor konstruksi jaring, khususnya hanging ratio, dan perilaku ikan terhadap, selain ukuran mata jaring yang berpengaruh terhadap selektivitas. Masalah resistensi nelayan terhadap regulasi dibahas dalam tulisan ini.
\end{abstract}

KATAKUNCI: pukat cincin, parameter biometrik, hasil tangkapan, selektivitas, Laut Jawa

ABSTRACT: Biometric parameters of catch of purse seine in the Java Sea related to its selectivity performance. By: Wijopriono and Mahiswara

Purse seine is the main fishing gear for pelagic fisheries in Java Sea with target species of small pelagic fish. The fishers applied mesh size of $19 \mathrm{~mm}$ at the bunt and $25 \mathrm{~mm}$ at the body and wing. While, the government has established to use mesh size of not less than $25 \mathrm{~mm}$ for the bunt and 51 $\mathrm{mm}$ for the wing. Research on the purse seine was done to evaluate its selectivity and to identify technical problems related to the resistence of the fishers in applying mesh regulation issued. Selectivity was evaluated using biometric characteristic approach, while the technical problems were identified through interviews. Based on the comparison of functional relationships among biometric parameters of the target species against mesh opening, the ranges of fish size enmeshed were estimated. It was found that for the same mesh size, fishes can be enmeshed at different fork length (FL) depending on their morphology. Both estimated and actual fish enmeshed showed the same tendency, where average sizes of $\boldsymbol{D}$. russelli and $\mathbf{S}$. crumenophthalmus enmeshed were smaller than those of $\boldsymbol{D}$. macrosoma and $\boldsymbol{R}$. kanagurta. The fact that range of actual size was $25 \%$ smaller and $13 \%$ larger than that of estimated size. This result revealed the existing of factors other than mesh size that influenced the selectivity. These factors considered as net construction, especially hanging ratio, and fish behaviour. Technical problems related to the resistence of fishers to the mesh regulation issue were discussed in this paper.

\section{KEYWORDS: $\quad$ purse seine, biometric parameter, catch, selectivity, the Java Sea}

\section{PENDAHULUAN}

Pukat cincin merupakan alat tangkap utama perikanan pelagis di Laut Jawa dengan sasaran kelompok ikan pelagis kecil, seperti selar (Carangoids), lemuru (Clupeoids), dan kembung (Scombroids). Lebih dari 50\% hasil tangkapan pukat cincin adalah ikan layang (Decapterus spp.), menyusul banyar (Rastrelliger spp.) 18\%, Siro (Amblygaster sirm) 7,4\%, selar bentong (Selar crumenopthalmus) dan juwi (Sardinella gibossa) masing-masing 7\%. Pada tahun 2005, pukat cincin mengkontribusi lebih dari 193.000 ton atau 32,5\% dari total hasil tangkapan ikan yang didaratkan di utara Jawa (Direktorat Jenderal Perikanan Tangkap, 2007).

Pukat cincin adalah alat tangkap yang bersifat aktif dan termasuk kelompok jaring lingkar (surrounding net) (Nedelec \& Prado, 1990). Jaring berbentuk empat persegi panjang, terdiri atas 2 bagian 
utama, yaitu badan (body) dan kantong (bunt, landing bag, dan brailing piece). Badan jaring merupakan keseluruhan bagian jaring yang terdiri atas beberapa panel di mana bagian ujung panel disebut sayap (wing). Kantong merupakan bagian di mana kawanan ikan yang telah terkurung akan terkonsentrasi sebelum diangkat ke dek kapal, terletak di salah satu ujung atau di tengah atas bagian badan. Prinsip penangkapan dari pukat cincin adalah mengurung kawanan ikan, yang bergerak bebas atau berkumpul di sekitar rumpon (FADs), sehingga ikan terkumpul di dalam jaring dan tidak terjerat (enmeshed) untuk mencegah beban tarik yang besar.

Melalui selektivitas mata jaring, ditentukan ukuran mata jaring yang sesuai dengan ukuran-ukuran ikan sasaran tangkapan. Mata jaring yang selektif berarti mata jaring yang memungkinkan tangkapan sampingan insidental (incidental bycatch) seperti yuwana, ikan-ikan muda, ikan-ikan kecil, spesies bukan sasaran, dan organisme hidup lain secara leluasa lolos dari mata jaring sehingga dapat tumbuh kembang (FAO, 1995a). Selektivitas ini dilaksanakan melalui seleksi mata jaring (mesh selection) yang menghasilkan panjang seleksi (length selection), terutama panjang saat ikan tertangkap pertama kali (length at first capture- $L_{50}, L_{c}$ ), yaitu panjang d imana $50 \%$ tertangkap dan $50 \%$ lolos dari mata jaring (Pope et al., 1975; Valdermarsen \& West, 1995; FAO, 1995b). Seleksi terhadap beberapa ukuran mata jaring akan menghasilkan beberapa faktor seleksi (selection factor), yaitu rasio antara $L_{c}$ dan mata jaring, di mana mata jaring yang selektif dapat ditentukan.

Sejak awal perkembangan pukat cincin di Laut Jawa, pemerintah telah mengeluarkan regulasi berkaitan dengan selektivitas mata jaring melalui Keputusan Menteri Pertanian No.123/Kpts/Um/3/ 1975 tanggal 31 Maret 1975 tentang ketentuan ukuran mata jaring purse seine untuk penangkapan ikan-ikan pelagis (Departemen Pertanian, 1987). Ditetapkan bahwa ukuran mata jaring pada bagian sayap tidak boleh kurang dari 2 inci dan pada bagian kantong tidak boleh kurang dari 1 inci. Konsiderasi dari regulasi yang didasarkan pada selektivitas alat tangkap ini adalah untuk mencegah penurunan stok ikan pelagis kecil di Laut Jawa. Pada kenyataan, secara operasional regulasi tersebut tidak dapat berjalan dengan baik. Nelayan tetap menggunakan pukat cincin dengan ukuran mata jaring 0,75 inci $(19 \mathrm{~mm})$ pada bagian kantong dan 1,00 inci $(25,4 \mathrm{~mm})$ pada bagian badan dan sayap.

Penelitian-penelitian selektivitas alat tangkap telah banyak dilakukan, namun untuk selektivitas pukat cincin terbatas. Terdapat beberapa metode pendekatan dalam penelitian selektivitas pukat cincin, antara lain metode pendekatan karakteristik biometrik (Gyulbadanov dalam Fridman, 1973), di mana karakter biometrik spesies ikan sasaran di lahan studi dijadikan dasar perhitungan dan analisis karakteristik selektivitas pukat cincin dilakukan berdasarkan pada hubungan morfometrik individual spesies dan karakteristik retensi mata jaring teoritis (Resma \& DeAlteris, 2005). Hayase et al. (1984) menerapkan metode cube shaped cages untuk mengevaluasi mata jaring pukat cincin pelagis kecil di Teluk Thailand. Sementara itu, beberapa penelitian selektivitas lain menggunakan metode test panel mesh, seperti dilakukan oleh Rulifson \& Cooper (1986) dalam mengevaluasi mata jaring pukat cincin yang menangkap menhaden, Brevoortia spp., dan Anonymous (2004) dalam penelitian selektivitas pukat cincin demersal di Portugal. Dua metode terakhir, terutama test panel mesh memerlukan waktu dan biaya yang tinggi dalam penerapan dibanding metode pertama.

Tulisan ini membahas parameter biometrik hasil tangkapan terkait dengan selektivitas pukat cincin dengan ukuran mata jaring yang secara aktual digunakan nelayan di Laut Jawa maupun yang ditetapkan dalam regulasi, serta permasalahan dalam penerapan. Pengaruh terhadap sumber daya ikan pelagis juga didiskusikan.

\section{BAHAN DAN METODE}

\section{Pengumpulan Data}

Tulisan ini didasarkan pada data yang dikumpulkan secara periodik pada tahun 2005. Pengamatan dan pengukuran dilakukan di pusat pendaratan ikan dan di atas kapal dengan mengikuti trip penangkapan pukat cincin. Contoh ikan dikumpulkan dari hasil tangkapan pukat cincin yang didaratkan di Pelabuhan Perikanan Nusantara Pekalongan, yang merupakan basis armada pukat cincin terbesar di pantai utara Jawa, dan di atas kapal di lokasi penangkapan ikan. Pengukuran parameterparameter biometrik ikan yang dilakukan, meliputi panjang cagak $(F L)$, keliling kepala $\left(G_{h}\right)$, dan keliling badan maksimum $\left(G_{\text {max }}\right)$ dari masing-masing spesies ikan pelagis dominan. Pengamatan langsung dan pengukuran parameter biometrik ikan dilakukan di atas kapal di lokasi penangkapan perairan Karimun Jawa. Kapal memiliki tonage 46 GT dengan tenaga penggerak $160 \mathrm{HP}$ dan panjang jaring $360 \mathrm{~m}$. Contoh ikan diambil secara acak dari 20 kali pengangkatan jaring. Pengamatan dan pengukuran panjang cagak $(F L)$ contoh ikan yang terjerat jaring juga dilakukan di atas kapal selama mengikuti trip penangkapan ikan. 


\section{Analisis Data}

Selektivitas mata jaring diestimasi menggunakan pendekatan karakteristik biometrik (Fridman, 1973; Resma \& DeAlteris, 2005). Ikan-ikan akan terjerat pada mata jaring atau terkurung di dalam jaring pukat cincin tergantung pada keliling mata jaring (4a) yang digunakan dan parameter biometrik $\mathrm{G}_{H}$ dan $\mathrm{G}_{\mathrm{MAX}}$ dari spesies ikan sasaran tangkapan. Ikan akan terjerat di bagian tubuh pada mata jaring jika:

$$
\mathrm{G}_{\mathrm{H}}<4 \mathrm{a}<\mathrm{G}_{\mathrm{Max}}
$$

di mana:

$$
\begin{aligned}
& \mathrm{a}=0,50 \mathrm{a}_{\circ} \\
& \mathrm{a}_{\mathrm{o}}=\text { ukuran mata jaring }
\end{aligned}
$$

Ikan akan terjerat di bagian insang jika $4 a=G_{H}$; akan terjerat pada bagian parameter maksimum jika $4 \mathrm{a}=\mathrm{G}_{\mathrm{MAX}} ;$; akan terkurung dalam jaring jika $4 \mathrm{a}<\mathrm{G}_{\mathrm{H}}$ dan meloloskan diri jika $4 a>G_{M A X}$.

Di antara ke-3 parameter biometrik ikan yang diamati, parameter panjang ikan (FL) merupakan parameter yang umum diketahui dan dijadikan dasar referensi ukuran ikan. Dengan demikian akan lebih mudah mengatakan ikan yang terjerat, terkurung jaring atau meloloskan diri, berdasarkan pada ukuran panjang ikan tersebut. Untuk itu, analisis regresi digunakan untuk mengetahui hubungan antara $\mathrm{FL}$ dengan 2 parameter biometrik lain $\left(G_{H}\right.$ dan $\left.G_{M A X}\right)$.

Selektivitas pukat cincin diestimasi berdasarkan pada FL yang terjerat, rata-rata terkecil yang terkurung (atau panjang ikan saat pertama kali tertangkap, $\mathrm{L}_{c}$ ), tidak tertangkap (atau meloloskan diri). Bukaan mata jaring pada pukat cincin, selain tergantung pada ukuran mata jaring juga pada rancang bangun, terutama koefisien pengerutan (shortening, E).

\section{HASIL DAN BAHASAN}

\section{Hubungan antar Parameter Biometrik}

Armada pukat cincin di Laut Jawa merupakan armada utama untuk penangkapan kelompok ikan pelagis kecil. Tercatat sekurang-kurang 6 spesies sepanjang tahun, dengan persentase tertinggi ikan layang (Decapterus spp.), menyusul banyar (Rastrelligerspp.), siro (Amblygaster sirms), bentong (Selar crumenopthalmus), dan jui (Sardinella gibossa).

Berdasarkan pada informasi ini, data-data parameter biometrik dikumpulkan dari 4 spesies ikan dominan yang terdiri atas 2 spesies layang, Decapterus macrosoma dan $D$. russelli, banyar (Rastrelliger kanagurta), dan bentong (Selar crumenopthalmus). Data ukuran $\mathrm{G}_{\mathrm{H}}, \mathrm{G}_{\mathrm{MAX}}$ dan $\mathrm{FL}$ dikumpulkan dari total 3.166 contoh, namun demikian data ukuran $G_{\text {MAX }}$ dari sebagian kecil contoh yang tersedia tidak diperoleh karena kondisi ikan yang tidak lagi segar dan akan menyebabkan bias dalam pengukuran. Deskripsi statistik dari parameter biometrik contoh yang diperoleh dapat dilihat pada Tabel 1 , sementara hubungan antara variabel $G_{H}, G_{M A X}$, dan FL berdasarkan pada hasil analisis regresi dapat dilihat pada Tabel 2.

Tabel 1. Deskripsi statistik ukuran $\mathrm{G}_{\mathrm{H}}, \mathrm{G}_{\mathrm{MAX}}$, dan $\mathrm{FL}$ dari contoh ikan pelagis kecil Table 1. Descriptive statistic of $G_{H}, G_{M A X}$, and $F L$ of small pelagic fish samples

\begin{tabular}{lcccc}
\hline \multicolumn{1}{c}{ Parameter/Parameter } & D. macrosoma & D. russelli & R. kanagurta & S. crumenophthalmus \\
\hline $\mathrm{G}_{1}(\mathrm{~mm})$ & $37-114$ & $37-115$ & $45-142$ & $51-163$ \\
Rata-rata $(\mathrm{mm})$ & 76,7 & 77,6 & 96,7 & 104,8 \\
SD $(\mathrm{mm})$ & 11,3 & 15,6 & 20,3 & 20,9 \\
$\mathrm{n}$ & 957 & 972 & 1237 & 703 \\
$\mathrm{G}_{\text {MAX }}(\mathrm{mm})$ & $40-106$ & $42-124$ & $48-155$ & $56-178$ \\
Rata-rata $(\mathrm{mm})$ & 81,5 & 81,7 & 104,9 & 110,8 \\
SD $(\mathrm{mm})$ & 11,1 & 15,5 & 22,3 & 22,0 \\
$\mathrm{n}$ & 787 & 821 & 1135 & 624 \\
FL $(\mathrm{mm})$ & $78-226$ & $63-218$ & $81-236$ & $77-222$ \\
Rata-rata $(\mathrm{mm})$ & 161,1 & 139,5 & 164,8 & 156,8 \\
SD $(\mathrm{mm})$ & 22,5 & 32,5 & 31,7 & 28,7 \\
n & 957 & 972 & 1237 & 703 \\
\hline
\end{tabular}

Seperti terlihat dalam Tabel 1, contoh ikan meliputi ukuran panjang cagak (FL) 78 sampai dengan 226 $\mathrm{mm}$ untuk $D$. macrosoma, 63 sampai dengan 218 mm untuk $D$. russelli, 81 sampai dengan $236 \mathrm{~mm}$ untuk $R$. kanagurta, dan 77 sampai dengan $222 \mathrm{~mm}$ untuk S. crumenophthalmus. Ukuran-ukuran ikan 
tersebut secara keseluruhan telah mewakili rentang ukuran masing-masing spesies ikan pelagis kecil yang tertangkap pukat cincin.

Hasil analisis regresi menunjukkan bahwa hubungan antara variabel $G_{H}$ dan $G_{\text {MAX }}$ dengan $F L$ untuk masing-masing spesies adalah linier seperti ditunjukkan dalam Tabel 2, dengan rentang koefisien determinasi $\left(R^{2}\right)$ 0,916-0,959. Konstanta pada persamaan-persamaan tersebut secara implisit mengindikasikan pebedaan bentuk badan (body shape) masing-masing spesies. Sebagai contoh, secara morfologis bentuk badan $D$. russelli lebih pipih (slender) dengan bentuk bagian atas kepala sampai dengan punggung (dorsal) lebih melengkung (curved) dibandingkan dengan $D$. macrosoma. Sejalan dengan itu, persamaan regresi menunjukkan bahwa pada ukuran panjang cagak (FL) yang sama $G_{H}$ dan $G_{\text {MAX }}$ dari $D$. russelli lebih besar dibandingkan dengan $D$. macrosoma.

Tabel 2. Hubungan antara $\mathrm{G}_{\mathrm{H}}, \mathrm{G}_{\mathrm{MAX}}$, dan $\mathrm{FL}$ berdasarkan pada analisis regresi dari contoh ikan pelagis kecil

Table 2. Relationships between $G_{H}, G_{M A X}$, and $F L$ derived from regression analysis of the samples of small pelagic fish

\begin{tabular}{|c|c|c|c|}
\hline Spesies/Species & $\begin{array}{c}\text { Hubungan antar parameter/ } \\
\text { Rejationship between parameters }\end{array}$ & $\mathrm{R}^{2}$ & $\mathbf{n}$ \\
\hline \multirow[t]{2}{*}{ D. macrosama } & $\mathrm{G}_{\mathrm{H}}=0,4836 \mathrm{FL}-1,19$ & 0,939 & 957 \\
\hline & $G_{m a x}^{n}=0,5279 \mathrm{FL}-1,45$ & 0,959 & 787 \\
\hline \multirow[t]{2}{*}{ D. russeiji } & $G_{H}=0,4632 \mathrm{FL}+13,01$ & 0,936 & 972 \\
\hline & $G_{\operatorname{Mx}}=0,5184 F L+13,80$ & 0,916 & 821 \\
\hline \multirow[t]{2}{*}{ R. kanagurta } & $\mathrm{G}_{\mathrm{H}}=0,6266 \mathrm{FL}-6,59$ & 0,959 & 1237 \\
\hline & $\mathrm{G}_{\mathrm{Mx}}=0,7098 \mathrm{FL}-10,29$ & 0,936 & 1135 \\
\hline \multirow[t]{2}{*}{ S. crumenophthaimus } & $\mathrm{G}_{\mathrm{H}}=0,7113 \mathrm{FL}-6,67$ & 0,958 & 703 \\
\hline & $\mathrm{G}_{m a x}=0,7686 \mathrm{FL}-6,79$ & 0,959 & 624 \\
\hline
\end{tabular}

\section{Seleksi Mata Jaring}

Sebagian besar alat tangkap bersifat seletektif terhadap ikan berukuran besar dan beberapa alat lain selektif bagi suatu kisaran panjang, sehingga dengan demikian tidak menangkap ikan-ikan yang berukuran sangat kecil dan juga yang sangat besar. Sifat-sifat demikian disebut selektivitas alat tangkap (Sparre \& Venema, 1998). Selektivitas tersebut merupakan instrumen penting bagi pengelola perikanan dalam penentuan ukuran minimum dari spesies target dari suatu perikanan tertentu melalui regulasi ukuran mata jaring yang digunakan.

Pada jaring trawl, selektivitas ditentukan berdasarkan pada ukuran mata jaring bagian kantong (Pope et al., 1975; Jones, 1976). Sementara itu, selektivitas untuk jaring insang ditentukan berdasarkan pada ukuran mata seluruh badan jaring.

Pukat cincin merupakan alat tangkap yang tersusun dari beberapa panel jaring dengan ukuran mata yang berbeda untuk setiap bagian atau bidang panel (Gambar 1). Ditinjau dari metode operasi, alat ini dapat dikatakan bersifat semi aktif bila dibandingkan dengan trawl, yang bersifat aktif, dan gill net, yang bersifat pasif. Pukat cincin pada dasarnya memiliki prinsip kerja seperti jaring trawl sekaligus gill net sejauh menyangkut seleksi alat tangkap. Namun, dalam penentuan selektivitas lebih komplikatif dibandingkan dengan traw/ dan gill net, sebab selain ada variasi ukuran mata pada satu unit jaring, alat ini dimanfaatkan untuk menangkap spesies ikan pelagis yang bergerombol. Spesies ini mempunyai tendensi membentuk kawanan yang terdiri atas ikan yang berukuran relatif sama (Sparre \& Venema, 1998). Dalam penelitian ini selektivitas pukat cincin diukur pada bagian badan jaring, yang merupakan bagian jaring terluas dalam konstruksi.

Probabilitas bahwa seekor ikan akan terjerat atau lolos melalui suatu mata jaring tergantung dari bentuk, khususnya ukuran lingkar kepala $\left(G_{H}\right)$ dan badan maksimum $\left(G_{M A X}\right)$ dibandingkan dengan ukuran mata jaring. Ukuran mata jaring didefinisikan sebagai panjang total mata jaring dalam keadaan direntangkan (stretched).

Berdasarkan pada karakteristik biometrik ikan-ikan hasil tangkapan pukat cincin di Laut Jawa dan model hubungan antar parameter-parameter dibandingkan dengan ukuran mata jaring yang digunakan, secara teoritis dapat diestimasi kelompok ukuran ikan yang terjerat, lolos, dan terkurung di dalam jaring. Dengan mengambil kisaran ukuran mata jaring antara aktual yang digunakan armada pukat cincin dan yang ditetapkan dalam regulasi, $19 \mathrm{~mm}$ (0,75 inci) sampai dengan 50,8 mm (2 inci), kelompok ukuran panjang masing-masing spesies ikan yang terjerat diestimasi seperti diperlihatkan pada Tabel 3. 

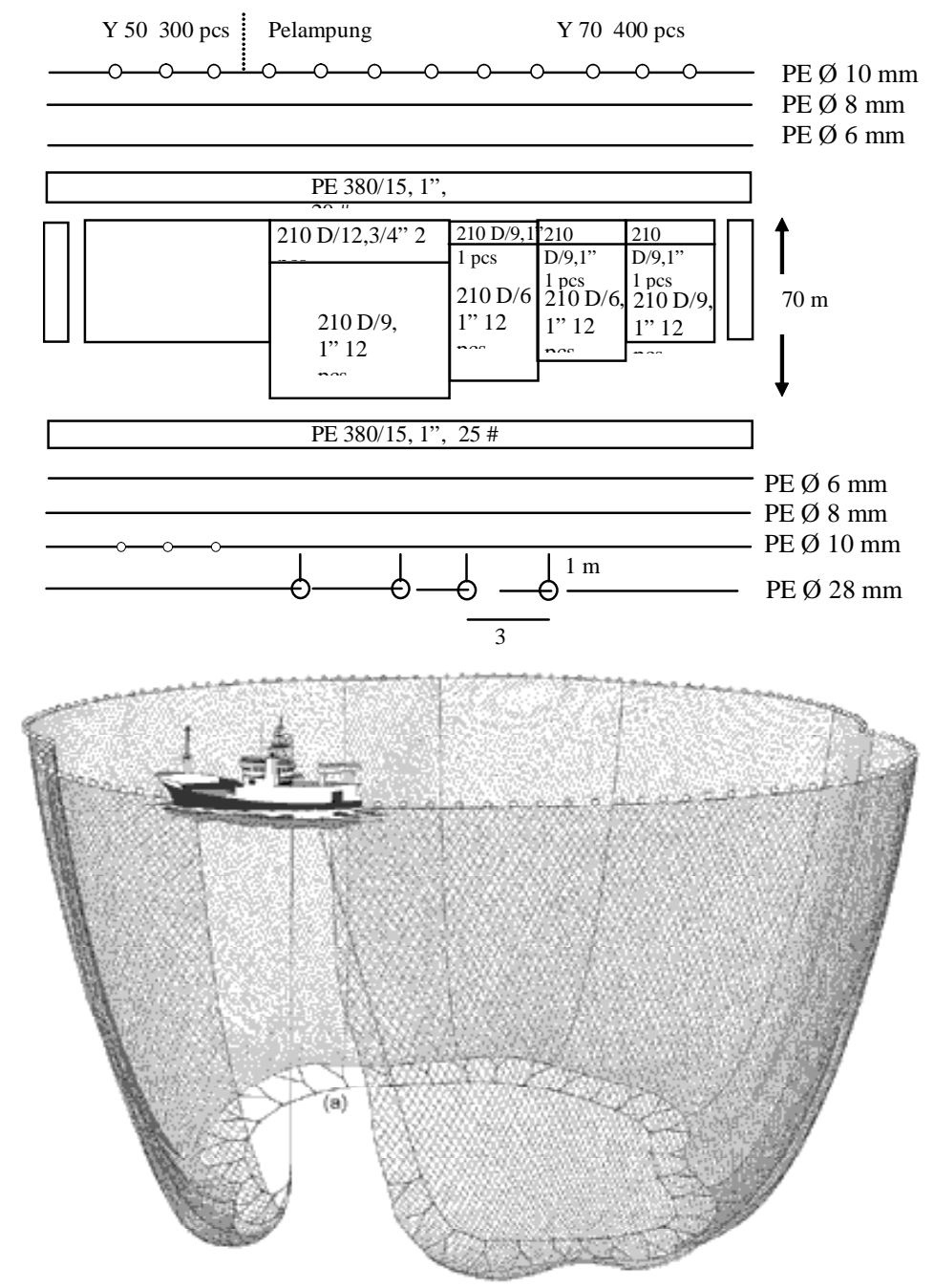

Gambar 1. Rancang bangun pukat cincin di Laut Jawa dan konfigurasi jaring dalam pengoperasian. Figure 1. Design of purse seine of the Java Sea and its configuration in the fishing operation.

Tabel 3. Kisaran ukuran panjang ikan yang terjerat pada berbagai ukuran mata jaring pukat cincin, diestimasi berdasarkan pada karakteristik biometrik hasil tangkapan

Table 3. Ranges of fish length enmeshed in variety of mesh size, estimated from biometric characteristic of the catches

\begin{tabular}{ccccc}
\hline $\begin{array}{c}\text { Mata jaring/ } \\
\begin{array}{c}\text { Mesh size } \\
(\mathbf{m m} / \mathbf{i n c i})\end{array}\end{array}$ & $\begin{array}{c}\text { D. macrosoma } \\
(\mathbf{m m})\end{array}$ & $\begin{array}{c}\text { D. russelli } \\
(\mathbf{m m})\end{array}$ & $\begin{array}{c}\text { R. kanagurta } \\
(\mathbf{m m})\end{array}$ & $\begin{array}{c}\text { S. crumenophthalmus } \\
(\mathbf{m m})\end{array}$ \\
\hline $19^{*} / 0,75$ & $75-81$ & $47-54$ & $68-71$ & $58-63$ \\
$25^{*} / 1$ & $98-106$ & $71-81$ & $86-91$ & $74-80$ \\
$38^{*} / 1,5$ & $147-160$ & $122-136$ & $122-132$ & $108-117$ \\
$51^{*} / 2$ & $194-211$ & $168-188$ & $156-171$ & $138-150$ \\
\hline
\end{tabular}

Keterangan/Remarks: * ${ }^{*}$ angka pembulatan

Pukat cincin di Laut Jawa menangkap kawanan ikan pelagis yang terdiri atas beberapa spesies. Pada berbagai skala (mini, medium, dan besar), armada perikanan ini menggunakan mata jaring dengan ukuran dan tata letak yang pada umumnya seragam. Estimasi berdasarkan pada pendekatan karakteristik biometrik ikan hasil tangkapan menunjukkan bahwa kisaran panjang ikan yang terjerat pada 1 ukuran mata jaring tertentu berbeda menurut spesies karena ada perbedaan morfologis. Dengan ukuran mata jaring yang sama, ukuran $D$. russelli yang terjerat lebih kecil dibandingkan $D$. macrosoma, $R$. Kanagurta, maupun S. crumenophthalmus. 
Dalam praktek, ikan yang terjerat ternyata berbeda dibanding hasil estimasi dalam hal rentang ukuran. Pengamatan menunjukkan bahwa rentang ukuran ikan yang terjerat pada jaring pukat cincin di bagian panel dengan ukuran mata $25 \mathrm{~mm}$ (1 inci) lebih lebar dibandingkan hasil estimasi. Perbandingan antara rentang ukuran ikan hasil estimasi dan aktual yang terjerat pada mata jaring $25 \mathrm{~mm}$ dapat dilihat pada Tabel 4 .

Tabel 4. Rentang ukuran ikan hasil estimasi dan aktual terjerat pada mata jaring $25 \mathrm{~mm}$ (1 inci) Table 4. Estimated and actual ranges of fish length enmeshed in the net of $25 \mathrm{~mm}$ (1 inch) mesh size

\begin{tabular}{|c|c|c|c|c|c|}
\hline \multirow{3}{*}{$\begin{array}{l}\text { Spesies/ } \\
\text { Speciec }\end{array}$} & \multicolumn{5}{|c|}{$\begin{array}{l}\text { Ukuran panjang (FL) ikan yang terjerat/ } \\
\text { Fish length enmeshed in the net ( } \mathrm{mm})\end{array}$} \\
\hline & Estimasi/Estimation & & Aktual/Actuality & & \\
\hline & Rentang/Range & Rentang/Range & Rata-rata/Average & SD & $\mathbf{n}$ \\
\hline D. macrosoma & $98-106$ & $82-112$ & 91,1 & 7,9 & 40 \\
\hline D. russelli & $71-81$ & $51-96$ & 77,0 & 12,6 & 52 \\
\hline R. kanagurta & $86-91$ & $60-103$ & 81,5 & 13,5 & 40 \\
\hline S. crumenophthalmus & $74-80$ & $51-94$ & 73,5 & 14,3 & 76 \\
\hline
\end{tabular}

Seleksi jaring tergantung dari sejumlah faktor selain ukuran mata jaring. Seperti juga jaring insang (e.g., Hamley, 1975), seleksi jaring pukat cincin tergantung juga pada konstruksi, visibilitas, bahan jaring, dan perilaku ikan. Faktor konstruksi alat yang menentukan probabilitas ikan dapat terjerat adalah daya rentang (stretchability) dan kelenturan badan jaring dalam air. Daya rentang ditentukan oleh rasio pengikatan jaring (hanging ratio) atau hanging coefficient (Sparre \& Venema, 1998). Kelenturan badan jaring dalam air ditentukan oleh perbandingan dalam (tinggi)-terpasang antara bagian kantong dan sayap (panel bagian ujung badan) jaring $\left(D_{B} / D_{N}\right)$.

Hanging ratio atau hanging coefficient (E) akan menentukan bentuk mata jaring. Koefisien ini juga menentukan kekendoran mata jaring, semakin kecil E semakin kendor jaring dan sebaliknya. Hanging ratio yang membuat bukaan mata jaring optimum adalah 0,707 , sedangkan pada jaring pukat cincin di Laut Jawa lebih kecil, berkisar antara 0,52 sampai dengan 0,65 (Nasution et al., 1997).
Hasil percobaan Riedel (1963) pada jaring gill net membuktikan bahwa dengan ukuran mata jaring yang sama, semakin kecil hanging ratio semakin besar probabilitas ikan untuk terjerat. Lebih jauh, penelitian tersebut juga membuktikan bahwa semakin kecil hanging ratio semakin kecil kisaran ukuran dari $95 \%$ ikan yang tertangkap. Sejauh menyangkut seleksi alat tangkap, prinsip gill net seperti tersebut di atas belaku juga untuk pukat cincin.

\section{Seleksi dan Struktur Ukuran Hasil Tangkap}

Struktur ukuran hasil tangkapan merupakan gambaran yang mewakili bagian struktur populasi yang dieksploitasi dan merupakan produk dari hasil seleksi alat tangkap. Berdasarkan pada hasil pengukuran terhadap contoh Decapterus macrosoma dan D. ruselli (Sadhotomo, 2007), struktur ukuran ikan hasil tangkapan pukat cincin di Laut Jawa dapat dilihat pada Gambar 2.

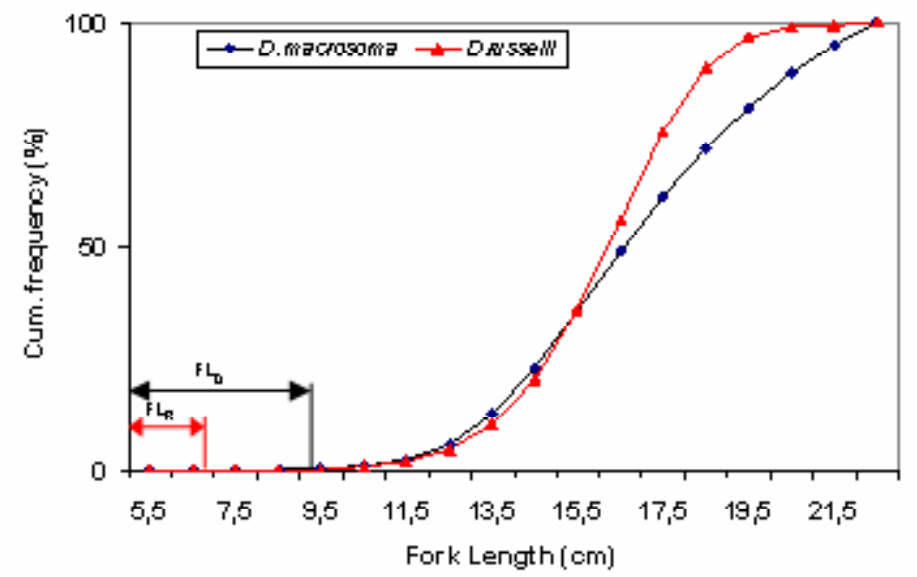

Gambar 2. Struktur ukuran hasil tangkapan pukat cincin di Laut Jawa.

Figure 2. Length structure of the catches of purse seine in the Java Sea. 
Berdasarkan pada struktur ukuran hasil tangkapan terdapat kelompok ukuran ikan yang semestinya dapat lolos dari jaring, sekitar $0,05 \%$ untuk $D$. macrosoma $\left(\mathrm{FL}_{\mathrm{D}}\right)$ dan lebih rendah untuk $D$. russelli $\left(F L_{R}\right)$. Hal ini, membuktikan ada faktor lain yang berpengaruh dalam seleksi, selain ukuran mata jaring. Merujuk hasil penelitian pengaruh cahaya pada alat bantu penangkapan pada pukat cincin (Mahiswara et al., 2005) diketahui bahwa kelompok ikan ukuran kecil cenderung berada di lapisan permukaan karena ketertarikan terhadap cahaya. Ikan-ikan kecil tersebut tertangkap karena ada mask effect, di mana terjadi penutupan mata jaring oleh ikan-ikan tangkapan berukuran lebih besar dilapisan yang langsung bersentuhan dengan jaring.

Dengan demikian, fakta bahwa terdapat perbedaan rentang ukuran ikan yang terjerat antara hasil estimasi dan aktual (Tabel 4), menunjukkan bahwa seleksi jaring pukat cincin selain ditentukan oleh ukuran mata jaring, juga dipengaruhi oleh faktor konstruksi alat, perilaku ikan, dan bahan jaring,. Berdasarkan pada Tabel 4 , lebar rentang ukuran ikan yang terjerat $25 \%$ lebih kecil dan $13 \%$ lebih besar dari hasil estimasi diduga merupakan pengaruh dari faktor-faktor di luar ukuran mata jaring tersebut.

Lebih lanjut, Gambar 2 juga menunjukkan bahwa ikan-ikan pelagis yang tertangkap pukat cincin mencakup rentang ukuran yang lebar, yaitu 5,5 sampai dengan 22,0 cm, dari ukuran ikan muda (immature) sampai dengan dewasa (mature). Kondisi ini tampak merupakan tipikal perikanan pukat cincin dengan tangkapan spesies campuran (mixed spesies), yang pada umumnya banyak dijumpai di wilayah-wilayah perikanan pelagis tropik. Di perairan Brazil, Lucena \& O'Brien (2001) menemukan bahwa pada lahan penangkapan yang sama, spesies ikan yang tertangkap pukat cincin menunjukkan rentang ukuran atau umur lebih lebar dibanding yang tertangkap gill net. Pukat cincin menangkap ikan dengan rentang umur ikan 1 sampai dengan 7 tahun sedangkan gill net menangkap ikan pada rentang umur 1 sampai dengan 5 tahun. Berkaitan dengan tipikal hasil tangkapan seperti ini, Thomson \& Ben-Yami (1984) mengklasifikasikan pukat cincin ke dalam kelompok alat tangkap yang kurang selektif.

Sudah menjadi postulasi bahwa semakin besar ukuran mata jaring yang digunakan, semakin tinggi probabilitas ikan muda atau ukuran kecil yang lolos. Dalam mencegah penurunan stok sumber daya ikan di Laut Jawa, reguasi ukuran mata jaring telah diberlakukan sejak awal melalui Keputusan Menteri Pertanian No.123/Kpts/Um/3/1975 tanggal 31 Maret 1975. Penetapan mata jaring $25 \mathrm{~mm}$ (1 inci) pada bagian kantong dan $51 \mathrm{~mm}$ ( 2 inci) pada bagian sayap secara teoritis akan meloloskan ikan lebih banyak dengan ukuran lebih besar seperti diperlihatkan pada Tabel 3. Pada tingkat operasional, regulasi ini tidak dapat berjalan karena beberapa alasan. Dari hasil wawancara dengan nakhoda kapal penangkap terungkap bahwa dengan stuktur ukuran ikan yang ada di Laut Jawa banyak ikan yang terjerat pada bagian kantong dan membuat mata jaring tertutup (mask effect) sehingga menyebabkan banyak jaring bagian kantong robek pada saat pengangkatan hasil tangkapan (resistensi jaring menjadi tinggi). Lebih lanjut, waktu yang diperlukan untuk membersihkan jaring menjadi lebih lama dan akan menghambat penurunan jaring (setting) berikut. Alasan lain adalah rendah margin keuntungan karena kemampuan tangkap (catchability) alat yang rendah.

Di luar hal tersebut, masalah yang menghambat penerapan regulasi adalah tidak ada barrier pasar. Seluruh hasil tangkapan pukat cincin dapat dipasarkan, baik ukuran besar, kecil, ikan muda, atau dewasa. Dengan demikian, tidak ada resiko pasar bagi nelayan untuk tetap menggunakan ukuran mata jaring seperti yang digunakan saat ini di mana ikanikan muda atau ukuran kecil banyak tertangkap. Persoalan lain yang akan timbul dari regulasi mata jaring pada perikanan pukat cincin di Laut Jawa, yang bersifat multi spesies, adalah penetapan ukuran mata jaring pukat cincin yang sesuai untuk membatasi penangkapan ikan muda dari satu atau beberapa spesies dapat memungkinkan hilang atau tertangkap ukuran dewasa siap mijah dari spesies ikan lain.

Terkait dengan regulasi mata jaring, Jones (1984) mengatakan bahwa perubahan dalam ukuran mata jaring tidak selalu mempunyai pengaruh terhadap perubahan struktur ukuran hasil tangkapan sesuai yang diharapkan. Hal ini, dikarenakan fluktuasi alami dari ukuran stok ikan cenderung pengaruh lebih besar daripada pengaruh yang diharapkan dari perubahan ukuran mata jaring yang di implementasikan. Ini bukan berarti regulasi mata jaring tidak ada pengaruh, tetapi pada praktek dalam perikanan pukat cincin pengaruh tersebut tidak akan terlihat secara jelas.

Bertolak dari masalah-masalah tersebut di atas dan karena pengaruh jangka pendek dari pembesaran ukuran mata jaring sesuai ketetapan regulasi adalah penurunan hasil tangkapan pukat cincin, maka tampak akan sulit meyakinkan nelayan atau industri perikanan bahwa regulasi mata jaring benar-benar diperlukan dan bermanfaat.

Persoalan dan hambatan yang timbul dalam penerapan regulasi mata jaring dalam perikanan pukat 
cincin telah mendorong banyak negara mencari alternatif untuk meningkatkan selektivitas pada perikanan pukat cincin, seperti penggunaan sorting grids, panel square meshes, atau diamond meshes (Goncalves et al., 2004; Anon, 2004; Valdermarsen \& West, 1995) Kemajuan yang telah dibuat dalam penelitian alat pereduksi hasil tangkap sampingan (by catch reduction device) tersebut kemudian diterapkan pada perikanan pukat cincin. Sebagai contoh, rigid metal sorting grids digunakan pada bagian kantong pada perikanan pukat cincin untuk menangkap saithe (Pollachius virens) dan Sea mackerel (Scomber scombrus) di Norwegia. Plastic panels digunakan pada bagian kantong pada pukat cincin untuk alat selektivitas ikan salmon di Canada (Anon., 1999).

\section{KESIMPULAN}

Berdasarkan pada hasil estimasi dan evaluasi terhadap selektivitas pukat cincin dapat ditarik kesimpulan bahwa:

1. Pada pukat cincin dengan ukuran mata jaring yang sama, ikan dapat terjerat pada ukuran yang berbeda tergantung dari bentuk morfologis, khususnya lingkar kepala $\left(G_{H}\right)$ dan lingkar badan maksimum $\left(G_{M A X}\right)$. Hasil estimasi melalui pendekatan biometrik maupun pengamatan langsung terhadap ikan-ikan pelagis yang terjerat menunjukkan kecenderungan yang tidak berbeda, di mana rata-rata ukuran $D$. russelli dan $S$. crumenophthalmus yang terjerat lebih kecil dari $D$. macrosoma maupun $R$. kanagurta.

2. Selektivitas pukat cincin selain ditentukan oleh ukuran mata jaring, juga dipengaruhi oleh faktor konstruksi jaring, khususnya hanging ratio, dan perilaku ikan. Perbedaan rentang ukuran antara hasil estimasi dan aktual ikan yang terjerat serta hasil evaluasi terhadap struktur ukuran hasil tangkapan membuktikan pengaruh faktor-faktor tersebut.

3. Penerapan regulasi berdasarkan pada ukuran mata jaring pada perikanan pukat cincin tampak sulit diterapkan pada tingkat operasional sejauh regulasi tersebut berpengaruh secara significant terhadap penurunan tingkat keberhasilan usaha.

\section{SARAN}

Kompleksitas permasalahan dari selektivitas dan performa alat tangkap modern adalah sedemikian sehingga mencoba membatasi efek yang kurang diinginkan dari penangkapan melalui peraturan dalam desain, ukuran atau spesifikasi alat tangkap yang digunakan nampak dalam banyak kasus kurang memberikan hasil. Untuk itu, disarankan:

1. Kebijakan penetapan ukuran mata jaring pada perikanan pukat cincin seyogyanya dilakukan atas dasar hasil penelitian menyeluruh dan hati-hati, baik menyangkut sifat dan tekno ekonomi alat tangkap maupun sumber daya sasaran tangkap, sehingga di satu sisi tidak berpengaruh terhadap kemampuan tangkap alat dan di sisi lain dapat menjamin kelestarian sumber daya ikan.

2. Dalam kasus di mana telah dilakukan penelitian terhadap alat tangkap secara baik dan menyeluruh, penerapan regulasi mata jaring mungkin merupakan komponen yang berguna dalam keseluruhan sistem manajemen. Namun demikian, jika regulasi mata jaring dibarengi dengan pembatasan ukuran kapal, akan lebih praktis dan efektif melakukan pengaturan terhadap kekuatan mesin daripada panjang atau gross tonnage kapal, karena pukat cincin bersifat aktif dalam pengoperasian.

\section{PERSANTUNAN}

Kegiatan dari hasil riset selektivitas unit penangkapan berbasis cahaya di perairan Laut Jawa, T. A. 2005, di Balai Riset Perikanan Laut, Muara BaruJakarta.

\section{DAFTAR PUSTAKA}

Anonymous. 2004. Experimental by catch reducing devices in the demersal purse seine fishery and evaluation of survivorship. Project Report FCTPOCTI/BSE/43113/2001. Universidade Do Algarve. Portugal.

Anonymous. 1999. A guide to selective salmon fishing in british columbia. Fiche D'Information BG-PR99-83E. Fisheries and Oceans. Canada.

Departemen Pertanian. 1987. Himpunan peraturan perundang-undangan bidang perikanan. Biro Hukum. Departemen Pertanian. pp. 141.

Direktorat Jenderal Perikanan Tangkap. 2007. Statistik perikanan Indonesia 2005. Direktorat Jenderal Perikanan Tangkap. Departemen Kelautan dan Perikanan. Jakarta.

FAO. 1995a. Code of conduct for responsible fisheries. FAO. Rome.

. 1995b. Methodology manual: Measurement of fishing gear selectivity. FAO. Rome. 
Fridman, A. L. 1973. Theory and design of commercial fishing gear. Israel Program for Scientific Translations. Jerusalem.

Goncalves, J. M. S., L. Bentes, P. Monteiro, R Coelho, M. Corado, \& K. Erzini. 2004. Reducing Discards in a Demersal Purse Seine Fishery. Project Report ICES K. 73-ASC 2004-VIGO.

Hamley, J. M. 1975. Review of gill net selectivity. Journal Fisheries Resources. Board Canada. 32. 1943-1969.

Hayase, S., S. Supengpan, \& P. Saikliang. 1984. A study on estimating the optimum mesh size of purse seines in the Gulf of Thailand. SEAFDEC and Department of Fisheries Thailand. Joint Research Paper. No. 6.

Jones, R. 1984. Mesh size regulation and its role in fisheries management. Papers presented at the expert consultation on the regulation of fishing effort (fishing mortality). FAO Fisheries Report. No.289. Supplement 2.

Jones, R. 1976. Mesh regulation in the demersal fisheries of the South China Sea area. South China Sea Fisheries Development and Coordinating Programme. SCS/76/WP/34.

Lucena, F. M. \& C. M. O'Brien. 2001.Effects of gear selectivity and different calculation methods on estimating growth parameters of blue fish. Pomatomus saltatrix (Pisces: Pomatomidae), from southern Brazil. Fisheries Bulletin. 99. 432-442.

Nasution, C., H. R. Barus, M. L. Linting, \& H. H. Latief. 1997. Identifikasi dan evaluasi hubungan antara dimensi jaring dan dimensi kapal pukat cincin melalui uji coba penangkapan dengan kapal pukat cincin 50 GT. Laporan Kegiatan Teknologi Penangkapan Tahun Anggaran 1996/1997. Balai Penelitian Perikanan Laut. Jakarta. Tidak diterbitkan.
Nedelec, C. \& J. Prado. 1990. Definition and classification of fishing gear categories. FAO Fisheries Technical Paper. No.22/1. FAO. Rome.

Pope, J. A., A. R. Margetts, J. M. Hamley, \& E. F. AkyÜz. 1975. Manual of methods for fish stock assessment. Part III. Selectivity of Fishing Gear. FAO Fisheries Technical Paper. No 41/1. FAO. Rome.

Resma, S. \& J. DeAlteris. 2005. The effect of the size selection characteristics of a Philippine tuna purse seine on the yield of the fishery: Preliminary results of theoretical and empirical analyses. In SNEC-AFS 2005 Abstracts. American Fisheries Society.

Riedel, D. 1963. Contribution to the experimental determination of the selection parameter of gill net. Arch. Fischereiwiss. 14. 85-97.

Rulifson, R. A. \& J. E. Cooper. 1986. A method to determine mesh size selectivity in commercial menhaden purse seines. North Am. Journal Fisheries Man. 6. 359-366.

Sadhotomo, B. 2007. Population dynamics of the main pelagic species exploited in the Java Sea: Stock evaluation. Indonesian Fisheries Resources Journal. 12. (1). 65-90.

Sparre, P. \& S. C. Venema. 1998. Introduction to tropical fish stock assessment. Part I. Manual. FAO Fisheries Technical Paper No.306/1. FAODANIDA.

Thomson, D. B. \& M. Ben-Yami. 1984. Fishing gear selectivity and performance. Papers presented at the expert consultation on the regulation of fishing effort (fishing mortality). FAO Fisheries Report No.289 Supplement 2.

Valdermarsen, J. W. \& C. W. West. 1995. Recent progress in developed countries in the methodology and equipment for selectivity research. In Expert and Industry Consultation on Selectivity in Asia. Beijing 12-17 October 1995. 